\title{
The Revisionary Influence: Neo-Victorian Fiction and the Past Redeemed
}

\author{
By Aleksandra Tryniecka*
}

According to James Eli Adams, 'the novel is an extraordinarily rich guide to Victorian culture" (O'Gorman, 2005, p. 52). Hence, the novel offers innumerable possibilities to encode and decode the past. While the Victorian era allowed the novel to enter the domestic sphere and initiated the development of the community of readers, it simultaneously influenced the modern reading habits (ibid., p. 3). Presently, neo-Victorian literature provides the revision of nineteenth-century fiction. As observed by Kate Mitchell, "the literature and culture of the Victorian period have been courted, sought and summoned across many facets of contemporary culture for more than three decades" (Mitchell, 2010, p. 3). In addition, Mitchell poses a question whether modern literature can "recreate the [Victorian] past in a meaningful way" or whether it is only capable of introducing the "nineteenth-century dress-ups" (ibid., p. 3). In my paper, I would like to examine the reciprocal relations between the Victorian and neo-Victorian fiction in order to account for the modern interest in the revival of the nineteenth-century past. Moreover, I argue that the interest in neo-Victorian texts proves that the revision of the past is necessary for the analysis of the present. Simultaneously, I claim that the modern revisionary fiction is not only a "dress-up," but also an endeavour to decode the past anew. While analysing the popular Victorian novelistic topics (including social hierarchy, family values, industrialism, crisis, disbelief, morality, marriage, money, spiritualism, visuality, disguises, double standards and performance), I argue that they are still valid and present in the modern era and, thus, deserve rethinking in the new context. On the whole, I claim that modern society is still rooted in the Victorian dilemmas and thus relies on the reassuring revival of the past. While literature emerges as the reliable link to the past, it serves as the contemporary tool of revision. In my study, I use Bakthin's theory of dialogism and such critical sources as: Kate Mitchell's History and Cultural Memory in Neo-Victorian Fiction, John R. Reed's Victorian Conventions, Francis O'Gorman's A Concise Companion to the Victorian Novel and Brantlinger's A Companion to the Victorian Novel.

Keywords: Victorian Fiction, Neo-Victorian Fiction, Victorian Culture, Bakhtin, Dialogism, Revision, Revival of the Past.

\section{Introduction: The Now and Then}

As James Eli Adams points out, 'the novel is an extraordinarily rich guide to Victorian culture" (O’Gorman, 2005, p. 52). It offers various possibilities to encode and decode the past. While Victorian era allowed the novel to enter the domestic sphere and initiated the development of the community of readers, it simultaneously influenced the modern reading habits (ibid., p. 3). Presently, neo-Victorian literature provides the revision of nineteenth-century fiction. As Kate Mitchell posits, "the literature and culture of the Victorian period have

${ }^{*}$ PhD Candidate, Maria Curie-Sklodowska University, Poland. 
been courted, sought and summoned across many facets of contemporary culture for more than three decades" (Mitchell, 2010, p. 3). In her work, Mitchell poses the question whether it is possible to "recreate the [Victorian] past in a meaningful way" or is it a "nineteenth-century dress-ups" (ibid., p. 3). In my paper, I would like to examine the reciprocal relation between the Victorian and neo-Victorian fiction in order to account for the significance of decoding the past anew.

\section{The Novel Domesticated}

The Victorian period witnessed the emergence of the readerly, "noveloriented community," as novels became the mainstay of nineteenth-century publishing, offering a new literary experience in the private sphere of life (Brantlinger \& Thesing, 2002, p. 3). According to Brantlinger and Thesing, novels were not favoured until the beginning of the Victorian era but, as they argue, "by the 1840s novel-reading was growing more socially acceptable" (ibid., p. 3).

The promising change in the perception of the novel in the Victorian era was initiated, as Brantlinger and Thesing observe (2002, p. 3), by Mudie's Select Circulating Library (1842). Subsequently, Dennis argues, the new means of transportation enhanced the reading habits - "the 'railway boom' between 1844 and 1847 gave a great boost to the fortunes of the lending library and a captive market to Mudie" (Dennis, 2000, p. 64).

At the same time, another competing "subcategory" embraced the socalled "railway novels" or "yellowbacks" which generally constituted, according to Brantlinger and Thesing, "translations or reprints" (2002, p. 5).

Concurrently, another branch of novels appeared in the form of "downscale street literature" referred to as "broadsides," evoking both a thrill and indignation (ibid., p. 4). Paradoxically, the "downscale novels" enjoyed good publicity and incorporated such "bestsellers" as G. W. M. Reynold's Mysteries of London (1840s), where the author regaled his readers with a "muckraking tourguide of London's underworld and nightlife" (ibid., p. 4). As a result, the novelistic market grew competitive and gradually extended its means to cater for diversified kinds of customers, including readers from various social classes, both commuting and restricted to the domestic sphere.

During the time of this literary transition, Victorian society underwent a parallel transformation as well, profiting from the new readerly opportunities. The novel not only offered a luring income to those engaged in the publishing process, but also complemented the socio-cultural mood of the period. As Brantlinger and Thesing pertinently remark, "novel-reading was as controversial as television-watching today" (Brantlinger \& Thesing, 2002, p.2).

Novel-reading triggered a new set of habits and social behaviours. Moreover, it established a special bond between readers, authors and critics. Society itself began to play the role of a literary critic.

Presently, as was initiated in the nineteenth century, reading habits are transmitted and inscribed in the contemporary culture, while the novel figures 
as a celebrated and distinguished genre. What is more, the specter of the Victorian novel re-enters the modern literary scene in the form of neoVictorian literature, defined by Louisa Hadley as "contemporary fiction that engage with the Victorian era, at either the level of plot, structure, or both" (Hadley, 2010, p.4).

\section{Revisioning the Past: In Search of the Truth?}

"Every text is haunted, every story is a ghost story, in the sense that all texts are haunted by the ghostly echoes of their predecessors," asserts Srdjan Smajic in his Ghost-Seers, Detectives and Spiritualists (2000, p. 15). Hence, neo-Victorian fiction enters the canon of modern literature in a spectral attempt at revisioning the past. Louisa Hadley, in her Neo-Victorian and Historical Narrative: The Victorians and Us, observes the "continued critical success of the [neo-Victorian] genre," highlighting such works as: "Margaret Atwood's Alias Grace (1996); Matthew Kneale's English Passengers (2000); Sarah Water's Fingersmith (2002); and Julian Barnes' Arthur \& George (2005)" (Hadley, 2010, p. 2). According to Hadley (ibid., p. 2), it is commonly accepted that neo-Victorian genre emerged in 1960s with the publications of Jean Rhys' Wide Sargasso Sea (1966) and John Fowles' The French Lieutenant's Woman (1969). As she asserts, the modern re-awakening of Victorian fiction can be related to the temporal location of modern society: "[r]emoved by a generation, we escape the 'anxiety of influence' that characterized the Modernists' reaction to the Victorians and prompted the disparagement of writers like Lytton Strachey and Virginia Woolf" (ibid., p. 7). Furthermore, Hadley posits that "the appeal of the Victorians is a result of the complex combination of their historical proximity to and distance from the contemporary era" (ibid., p. 14). Hence, paradoxically, the Victorian age appears both remote and familiar enough to attract and influence the modern recipient.

"History is no longer a stable entity, the assurance of an extra-textual reality or context against which literature can be understood," observes Kate Mitchell, drawing a line between historical and literary studies (Mitchell, 2010, p. 24). A similar observation stems from Louisa Hadley's work, where she highlights the twentieth-century shift in the perception of history from the "facts-based" approach to the "interpretation of the past" (Hadley, 2010, pp. 25-26):

[t]he element of the new history that provoked most controversy was the use of empathy: a mode of understanding the past that encouraged students to use their imagination in order to think themselves back into the lived experience of the people in the past (Hadley, 2010, p. 26). 
Consequently, the task of the neo-Victorian genre lies not in arguing for historical legitimacy but in revisioning the past in its multidimensional contexts. Moreover, the reflective approach to neo-Victorian fiction promotes a conscious and intimate encounter with the idea of the past.

Furthermore, I argue that rediscovering the literary past enables one not only to glance into the bygone, but also to examine the present, if also not to make predictions about the future. The "bi-directionality of neo-Victorian fiction" (Hadley, 2010, p. 15) - its engagement with the past and its origins in the present - enable the reader to occupy a liminal position on the dialogic threshold, where numerous literary voices can be located and heard. Hence, Bakhtin's dialogic approach excellently inscribes itself into the study of neoVictorian novel.

According to Bakhtin, the creator of the novel is capable of abolishing the gap between the past and the present. In effect, the past comes to light as something innovative and different, as if seen through a magnifying glass. Bakhtin posits this claim on the example of a remote object described in the text: "[n]o matter how distant this object is from us in time," he asserts, "it is connected to our incomplete, present-day, continuing temporal transitions, it develops a relationship with our unpreparedness, with our present" (Holquist, 2011 , p. 30). This phenomenon finds numerous examples in the field of neoVictorian literature, where the "ghostly" past is brought back from the remote sphere deprived of the immediate contact with the present. In neo-Victorian texts, the past becomes almost tangible - it can be formed anew into a shape never thought of before. Consequently, the author of the novel molds the past into a shape influenced by the modern context. Such process can be perceived as a kind of appropriation of the past. Thus, neo-Victorian fiction "excavates", revisits and foregrounds the new aspects of the literary past.

Bakhtin's fundamental claim is that dialogue underpins each literary construct. He highlights the importance of dialogic tradition and traces it back to antiquity. In the essay entitled "Epic and Novel," Bakhtin stresses the relevance of the Socratic dialogues, pointing out that they serve as the critical documents for paving the way for the modern dialogic genre: "We possess a remarkable document that reflects the simultaneous birth of scientific thinking and of a new artistic-prose model for the novel (...)," he argues, "[t]hese are the Socratic dialogues" (Holquist, 2011, p. 24). Moreover, Bakhtin believes that the novel stands in sharp contrast with the high genres. Understood as the plurality of voices unfolding in the text, the novel offers a dialogue with no "dominant force or truth" (ibid., p. 20). Novelistic discourse unfolds like the Socratic conversation aiming at the conscious recognition of the world rather than at rhetorical discourse inclined towards conclusiveness. Thus, the novel figures as an open, constantly developing genre.

Importantly, the author of the novel does not refer to the literary creation from a distance. Rather than that, the author is located on the common plane with the text. The innovative placement of the author allows the creator of the novel to abolish the gap between the present and the depicted past. In effect, the past comes to light as if viewed through a magnifying glass. Bakhtin explicates this claim on the example of a remote object described in a potential 
novel: "No matter how distant this object is from us in time," he asserts, "it is connected to our incomplete, present-day, continuing temporal transitions, it develops a relationship with our unpreparedness, with our present" (ibid., p. 30). This phenomenon finds numerous examples in the field of the neoVictorian literature, where the past is brought back from the remote sphere seemingly deprived of contact with the present.

\section{Looking In the Mirror, Seeing the Victorians}

"We read to assert ourselves, to sharpen our analytical faculties. We read to debunk the myths. We read to know the other (...)," argues Mark Edmundson in his Why Read? (2004, p. 52). Hence, as Edmundson observes, it is impossible to arrive at the "ultimate truth" during the reading process. However, while reading, one faces the past and reanalyzes it in the present context. Hence, the past always appears as an innovative experience. Consequently, neo-Victorian texts provide a sense of reassurance that modern society is not historically isolated, but rather still merged in the Victorian dilemmas.

While analyzing Victorian fiction, one can observe numerous topics that are still pending and valid in the twenty-first century literary discourse. Among these, one can find: social hierarchy, social transitions, family values, double standards, false morality, the issue of marriage, performativity, disguise, industrialism, money, crisis, disbelief, insecurity, the status of men among other species, spiritualism and personality. Thus, paradoxically, while mirroring the Victorian past, neo-Victorian texts reflect on the modern era as well. Literary revisioning becomes doubly significant, not only as the process commemorating the past, but also celebrating the present and acknowledging historical consequentialism.

In my paper, I would like to concentrate exclusively on the issues of social insecurity, social and moral transition and its strengths and weaknesses, as well as personality constructs and identity crisis as presented in the Victorian and neo-Victorian fiction.

\section{Social Insecurity and Personality Construct}

One of the nineteenth-century dilemmas exemplified in Victorian fiction embraces the issue of social insecurity - a "gradual declension in the power and centrality of conscious processes and the human will" (O'Gorman, 2005, p. 101), strongly depicted in such works as Thomas Hardy's Jude the Obscure (1895) or George Elliot's The Mill on the Floss (1860).

In the twenty-first century, neo-Victorian texts are still haunted by existential problems, facing the issues of insecurity, fate and self-will. Moreover, there is a growing interest in analyzing human's personality. The process of "psychologizing" neo-Victorian fiction reflects the modern interest in one's inner life and echoes Victorian preoccupation with human nature. In Clare Boylan's Emma Brown (2003), the eponymous heroine dons several 
alternative personalities and it is the reader's task to discover Emma's "true face." Similarly, in Margaret Forster's Lady's Maid (1990), the complex insight into Elizabeth Barret Browning's mind disturbs the claim that personality can be consistent or one-dimensional. Essentially, both Emma Brown and Elizabeth Browning are presented against the social background that reacts to their decisions and transformations.

In Lady's Maid, Margaret Forster highlights the issue of one's changing role in the society as well. In the final chapter of the novel, Wilson, the eponymous lady's maid, decides to free herself from the multifaceted social roles and their restraining influence:

Never again would she tie her life to another person in quite that way but would seek to stand on her own more truly than had ever been possible. (...) Her days as a lady's maid, which even when they were actually over she had refused to accept as finished, had died with her lady [Elizabeth Barret Browning]. Now, she could be herself and not poison what was left of her life with regrets and resentments. The yoke was lifted, and what she had been required to do and be, under it, should have no relevance to her future. She was a lady's maid no longer" (Forster, 2005, p. 534).

\section{Social Transition and Morality}

Thus, another dominant theme in Victorian fiction embraces the concept of "society" and concentrates on its transition which, according to Alexandra Köhler, stands for the transformation "from a feudal and agricultural society into an industrial democracy" (2007, p. 2). The "social transition" themes addressed by nineteenth-century writers reflect on the new urban mode of life and the advanced possibilities of commuting, drawing on the growing expectations of Victorian men and women. The year 1836 marked the appearance of the first train in London operating between London Bridge and Greenwich (O'Gorman, 2005, xv). The Industrial Revolution, initiated in Britain and sustained until 1840, influenced not only the technological growth but also produced new standards of collective morality. Consequently, social divisions were perpetuated hand in hand with the economically motivated morality. As Ermarth observes, "[t]he idea that society is an economic entity is an almost theological idea" (1997, p. 136). Accordingly, the novel became engaged with the idea of an "individual" and his or her suspension between idealistic social possibilities and their apparent lack in the "real," financially governed world. Thomas Hardy's Jude the Obscure serves as the most emphatic example of such a suspension. On the other hand, Charlotte Brontë's Jane Eyre (1847) describes the heroine's victorious struggle for a virtuous life and highlights her moral endurance, while drawing on her Cinderella tale.

In Brontë's work, it is the moral value that unceasingly wins over the fate. Clare Boylan revisions this approach to morality in her neo-Victorian novel Emma Brown, where she explicitly concentrates on the hardships awaiting the heroine before her final triumph. In Emma Brown, the heroine becomes a victim of the social confusion, as she paces the dark streets of London, 
unaware of the dangers awaiting her at every corner. As one reads in the final chapter of the novel,

(...) past had plucked her [Emma] from a place of privilege and cast her into valley of destitution. She had been dispossessed, abused, accused. It was an arduous passage for one so young, yet she had emerged strong and unafraid. Heaven grant her life would be calm from this day forth, that the smile which had begun to remould he resolute mouth would have long tenure. (...) The God who kept her safe on her travels never fashioned her for satin and silk" (Boylan, 2004, pp. 431-432).

It is Emma's moral strength that uplifts her, although it does not offer miraculous solutions, as in the "Cinderella story" of Jane Eyre. Instead, Emma's hard work grants her redemption in the economically oriented world. In Chapter Thirty Five, while looking after an orphaned girl, Emma realises that she is economically powerless, even though she is virtuous and upright: "[s]he was gripped by a sense of remembered dread so wrong that all the gay spring scene around her seemed to vanish. They had no money" (Boylan, 2004, pp. 391-392). Hence, in Emma Brown, the present-day concerns are resurrected in the Victorian setting.

However, Boylan's modern work offers a dialogical alternative to Hardy's hopeless pessimism and Brontë's miraculous moral victory: Emma wins because she works hard and, thus, she is capable of controlling her fate.

\section{Cultural and Identity Crisis}

Another moral transition witnessed by the Victorian era was prompted by Charles Darwin's evolutionary theory offered in his work On the Origins of Species, published in November 1859. The idea of Social Darwinism, evolving in the end of the nineteenth century, provided grounds not only for the "intellectual progress," but also for the cultural and identity crisis. Consequently, the cultural depression, identity crisis and moral uncertainty counted among the concerns of the Victorian novel. For instance, Charlotte Brontë's Villette (1853) depicts the inner struggle of Lucy Snowe who strives to attain her sense of belonging in a foreign country. While concealing her personality, Lucy strives to adapt to the new environment by means of performance.

The problem of the lost "self" echoes in Jean Rhys' modern novel as well. Wide Sargasso Sea deals with the issue of false morality, bereavement and inequality, as the heroine -Antoinette - becomes deprived of her identity due to her seemingly "ill" origins. Finally, Antoinette escapes into an imaginative reality where she seeks protection and comfort. Antoinette's deprivation is accentuated by her isolated surrounding in England which brings the painful memories of the past: 
... [t] here is no looking-glass here and I don't know what I am like now. I remember watching myself brush my hair and how my eyes looked back at me. The girl I saw was myself yet not quite myself. Long ago when I was a child and very lonely I tried to kiss her. But the glass was between us - hard, cold and misted over with my breath. Now they have taken everything away. What am I doing in this place and who am I? (Rhys, 1968, p. 116).

In Wide Sargasso Sea, Antoinette's gradual namelessness triggers the loss of her identity. When the heroine's vicious husband creates for her an alternative name, Antoinette states: "[n]ames matter, like when he wouldn't call me Antoinette, and I saw Antoinette drifting out of the window with her scents, her pretty clothes and her looking-glass" (Rhys, 1968, p. 116). Antoinette's identity crisis generates her vulnerability and prompts the final fall. Deprived of her name, the heroine sees her "true" self "drifting out of the window" (ibid., p. 116). Her moral strength is not enough to uplift her, as she is devoid of financial means as well. The narrative created by Antoinette in Rhys' novel is the only and final possession of the heroine striving to preserve her sense of existence.

In Clare Boylan's neo-Victorian work Emma Brown, the heroine also undergoes trials that prove her moral strength. Essentially, this strength is based on financial independence and it is the struggle for a decent work that is primarily highlighted in Boylan's text. Hence, in Emma's case, morality, stability and work serve as the foundation on which the heroine builds her future life.

Additionally, Boylan's work provides an insightful commentary on the social inequalities afflicting Victorian women. As an orphaned young woman, Emma struggles to free herself from the social hierarchy based on the patriarchal pattern. As Boylan highlights, Emma remains suspended between two choices: accepting her poverty and degradation or becoming a loveless wife. The Victorian "proper" choice thus embraces being "an obedient wife to [the] spouse and a loving mother to [the] children" (Boylan, 2004, pp. 113114). However, Boylan's neo-Victorian reworking of Jane Eyre offers the third liberating solution - independence. Hence, Boylan's work innovatively relieves Victorian heroines from the vicious "death or marriage" circle and offers them a modern choice. In this sense, the past becomes redeemed by the twenty-first century discourse.

\section{Conclusion}

While Victorian novels dwell on such issues as: morality, personality, society, insecurity and identity, neo-Victorian texts unceasingly echo these themes, engaging into an open dialogue with the literary past. Accordingly, the Victorian literary past opens up with new historical possibilities and allows one to rediscover the bygone in the contemporary context. As Mitchell observes, nowadays "history is conceived as a knowable space available to 
representation" (2010, p. 18). Moreover, the recurring interest in nineteenthcentury literature proves that Victorian dilemmas are strongly enrooted in the contemporary world. In the modern literary encounter, the past and the present simultaneously address and supplement each other, revealing their mutual dependence and dialogic co-existence. Consequently, the Victorian past becomes approximated to the reader's zone and the nineteenth-century literary realm transforms into a semi-modern and valid experience.

As Louisa Hadley asserts after Thomas Carlyle, "[h]istory (...) needs to incorporate both its scientific and literary impulses in order to provide the fullest possible account of the past" (Hadley, 2010, p. 23). Hence, while read dialogically and empathetically, literary texts constitute an undeniable proof that while looking back at the Victorians, we still face ourselves.

\section{References}

Boylan, C., 2004. Emma Brown. London: Abacus.

Brantlinger, P., \& Thesing, W.B., eds., 2002. A Companion to the Victorian Novel. Oxford: Blackwell Publishing.

Carlyle, T., 1840. Chartism. London: James Fraser, Regent Street.

Dennis, B., 2000. The Victorian Novel. Cambridge: Cambridge University Press.

Edmundson, M., 2004. Why Read? New York: Bloomsbury Publishing.

Ermarth, E.D., 1997. The English Novel in History: 1840-1895. London: Routledge.

Forster, M., 2005. Lady's Maid. London: Vintage Books.

Hadley, L., 2010. Neo-Victorian Fiction and Historical Narrative: the Victorians and Us. London: Palgrave Macmillan.

Holquist, M., ed., 2011. Dialogic Imagination. Four Essays by M.M. Bakhtin. Translated by C. Emerson \& M. Holquist. Texas: University of Texas.

Köhler, A., 2007. Social Class of the Mid-Victorian Period and Its Values. Norderstedt: Grin Verlag.

Mitchell, K., 2010. History and Cultural Memory in Neo-Victorian Fiction. New York: Palgrave Macmillan.

O'Gorman, F., ed., 2005. A Concise Companion to the Victorian Novel. Oxford: Blackwell Publishing.

Rhys, J., 1968. Wide Sargasso Sea. London: Penguin Books.

Smajić, S., 2000. Ghost-Seers, Detectives, and Spiritualists: Theories of Vision in Victorian Literature and Science. Cambridge: Cambridge University Press. 
